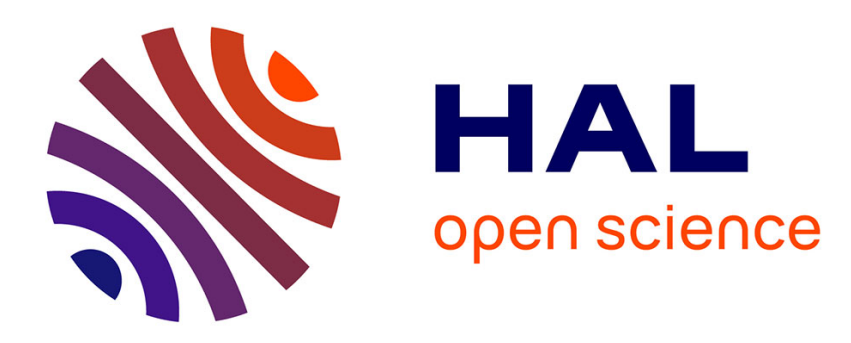

\title{
FAST REACTION SINTERING PROCESS FOR THE PRODUCTION OF FERRITES
}

\author{
M. Ruthner
}

\section{To cite this version:}

M. Ruthner. FAST REACTION SINTERING PROCESS FOR THE PRODUCTION OF FERRITES. Journal de Physique Colloques, 1977, 38 (C1), pp.C1-311-C1-315. 10.1051/jphyscol:1977164 . jpa00217024

\section{HAL Id: jpa-00217024 \\ https://hal.science/jpa-00217024}

Submitted on 1 Jan 1977

HAL is a multi-disciplinary open access archive for the deposit and dissemination of scientific research documents, whether they are published or not. The documents may come from teaching and research institutions in France or abroad, or from public or private research centers.
L'archive ouverte pluridisciplinaire HAL, est destinée au dépôt et à la diffusion de documents scientifiques de niveau recherche, publiés ou non, émanant des établissements d'enseignement et de recherche français ou étrangers, des laboratoires publics ou privés. 


\title{
FAST REACTION SINTERING PROCESS FOR THE PRODUCTION OF FERRITES
}

\author{
M. J. RUTHNER \\ Ruthner Industrieanlagen AG A-1121 Vienna, Austria
}

\begin{abstract}
Résumé. - On a étudié la formation de poudres de fcrrites au moyen d'un frittage à réaction rapide qui utilise des coulis activés d'hydroxydes métalliques, d'oxydes métalliques et/ou de carbonates métalliques comme matériaux de départ.

Certaines propriétés des ferrites de $\mathrm{Mn}-\mathrm{Zn}$ ainsi que des ferrites de Ba produits par cette méthode de frittage rapide ont été étudiées. Les résultats indiquent que le préfrittage de n'importe quel ferrite peut être effectué en quelques secondes à des températures habituelles. Certains faits indiquent que la méthode de frittage à réaction rapide peut être considérée comme une alternative sophistiqué pour produire des poudres de ferrites présentant des propriétés physiques et chimiques contrôlées avec précision.

Compte tenu de l'état actuel du savoir faire on conclut que les poudres de ferrites de Mn-Zn produites par frittage à réaction rapide peuvent être utilisées comme des produits finis. Ce procédé est en cours de développement dans le cas des poudres de ferrites durs.
\end{abstract}

\begin{abstract}
The formation of ferrite powders by means of fast reaction sintering using activated slurries of metal hydroxides, metal oxides and/or metal carbonates as raw materials has been investigated. Some properties of manganese zinc ferrite as well as bariumhexaferrite powders produced by means of fast reaction sintering were examined. The results indicate that presintering of any ferrites may at conventional temperatures within a few seconds be accomplished. Some facts indicate that the FRS method may be considered an advanced alternative to produce ferrite powders exhibiting precisely controlled physical and chemical propertics.

According to the present state of know-how it is concluded that fast reaction sintered manganese zinc ferrite powders may be used for finished products. As far as hard ferrite powders are concerned the process is being developed.
\end{abstract}

1. Introduction. - Previous investigations [1], concerning the preparation of coprecipitated refractory spinel powders by means of thermal decomposition of corresponding aqueous metal chloride solutions led to the conclusion that complete spinel formation may within a few seconds be accomplished at temperatures as low as $750^{\circ} \mathrm{C}$. This coprecipitation method is however not applicable to ferrite powders in general since the thermodynamic properties of applied metal chlorides, which are subject of thermal decomposition at elevated temperatures, are too manifold to yield ceramic powders exhibiting desired chemical and physical properties.

Having in mind that fast formation of spinel powders took place at ambient conditions providing short distances for cation diffusion and high driving forces for order mechanism as well as crystal growth, it has been suggested to accomplish ferrite formation by means of fast reaction sintering (FRS) using activated slurries of metal oxide components as raw materials in order to overcome thermodynamic facts previously mentioned. This paper comments on some properties of fast reaction sintered ferrite powders.

2. Experimental Procedure. - A general flowsheet of process steps for FRS is presented in figure 1.

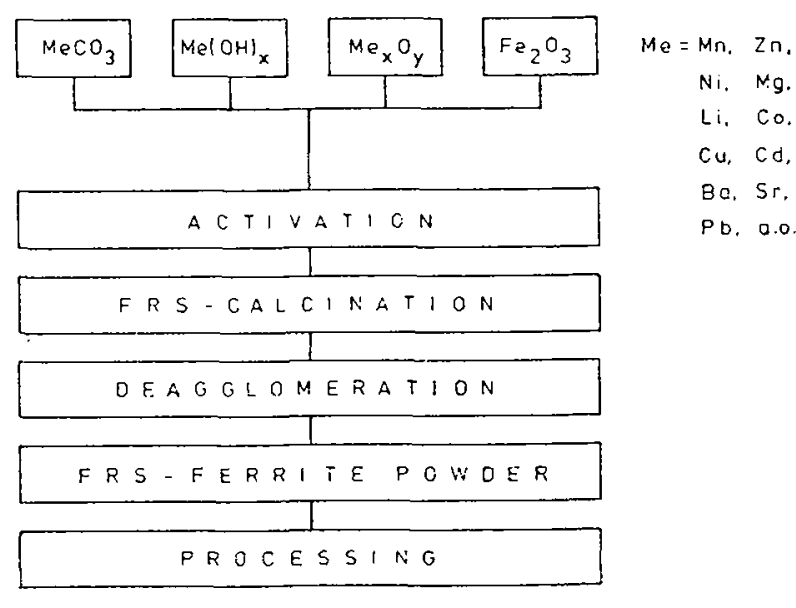

FIG. 1. - Schematic presentation of the FRS process.

3. Raw materials. - Spray roasted iron oxide $[2,3$, $4,5,6]$ and raw materials of commercial purity have been used for the experiments.

4. Slurry preparation. - Deionized water has been used for preparing slurries exhibiting desired ferrite composition. The mechanical activation has been accomplished by means of wet milling up to desired particle sizes. 
The particle diameters have been calculated from specific surface area data which have been measured according to the dynamic BET nitrogen absorption method [9]. Wet milling was strongly dependent on the nature of raw materials. Slurries containing up to $750 \mathrm{~g}$ of solids per liter have been prepared.

5. Fast reaction sintering furnace. - The furnace may be considered to be an especially designed spray calciner which provided a maximum temperature of about $1050^{\circ} \mathrm{C}$. The furnace had a temperature profile which ensured that no deviation of the desired chemical analysis will occur inside the reactor. The experiments have been carried out at temperatures between $900^{\circ} \mathrm{C}$ and $1050^{\circ} \mathrm{C}$. Further increase of the maximum firing temperature was at the time limited by mechanical parts of construction.

The activated slurry became directly fed to the FRS furnace forming spherical agglomerates which exhibited a high open porosity suitable to withstand $\mathrm{H}_{2} \mathrm{O}$ and $\mathrm{CO}_{2}$ dissociation pressures of specific raw materials.

During firing the oxide reactants became for a few seconds in direct contact with the hot combustion gases. The maximum firing temperature was taken from the hotest spot located above the burner chambers. A modified propan butan gas has been used as a fuel. The total retention time of the agglomerates in the FRS furnace was limited to about 15 seconds. The heat treatment of the oxide agglomerates at maximum sintering temperatures was limited to about $30 \%$ of the total retention time.

Variable oxidizing conditions in the order of a few percent oxygen excess have been provided during the execution of the experiments. For some tests protective gas has been used during powder cooling in order to avoid reoxidation phenomena.

The experimental plant had the capacity to produce $300 \mathrm{~kg}$ of FRS powder per hour. The plant has been operated round the clock and the loss of materials has been eliminated by means of solids recycling. Due to provided raw materials no neutralization or acid regeneration systems were required.

6. Deagglomeration. - Since fast reaction sintered ferrite powder consists of agglomerates of crystals for most applications a short deagglomeration procedure is essential.

7. Results and Discussions. - 7.1 SOrT rirRrItes. - Presintered manganese zinc ferrite powders exhibiting chemical compositions which are suitable for the production of $U$ and $E$ type, shell cores have been prepared by means of a conventional method and fast reaction sintering. By consulting figure 2.1, the X-ray diffraction pattern of the activated raw material slurry is evident. Figure 2.2 shows a spray dried and conventionally at $950^{\circ} \mathrm{C}$ for one hour presintered manganese zinc ferrite powder and figure 2.3 the

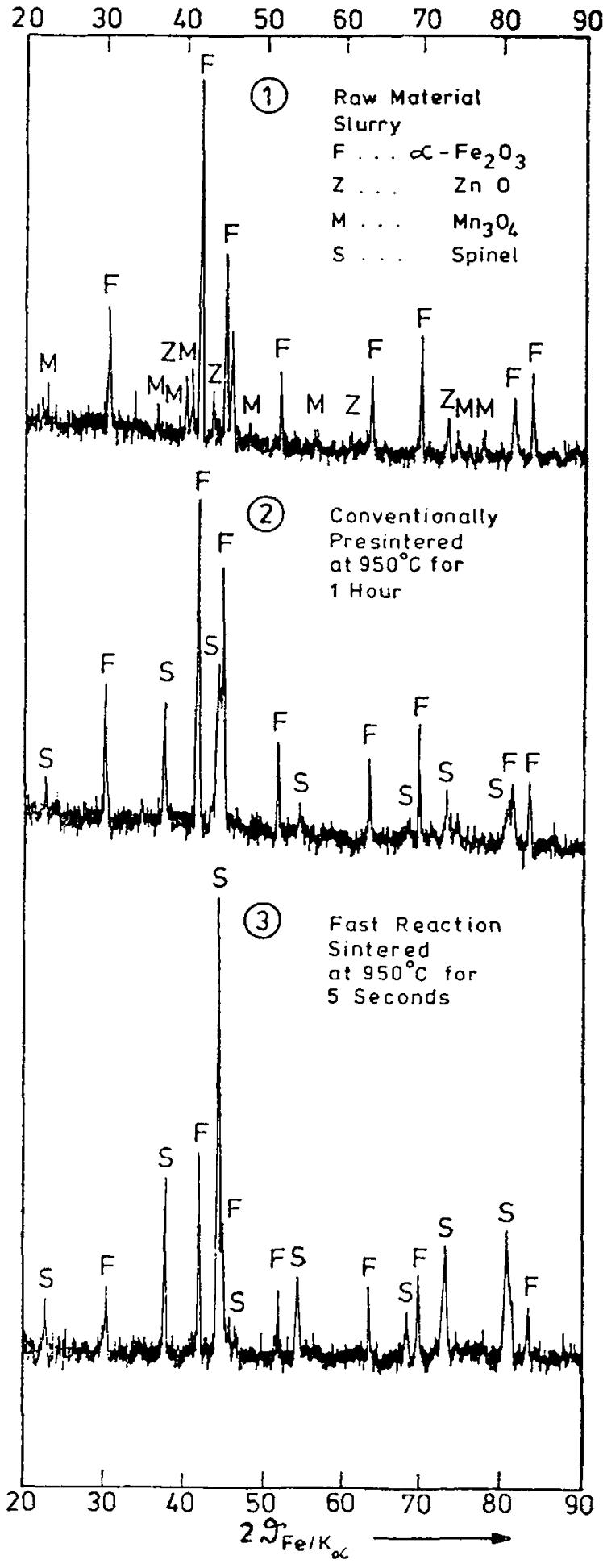

Fig. 2. - X-Ray Diffraction Patterns of manganese zinc ferritc powders (1) Ray Material sturry ; (2) Conventionally presintered ; (3) Fast reaction sintered

corresponding FRS product which has been presintered at $950^{\circ} \mathrm{C}$ for 5 seconds. A comparison of the diffraction patterns indicates that the spinel formation may very rapidly be accomplished by means of fast reaction sintering. The amount of nonreacted $\mathrm{Fe}_{2} \mathrm{O}_{3}$ 
was about $7 \%$. The presence of free ferric oxide is not necessarily due to nonreacted ferric oxide, which may be concluded by consulting the equilibrium $\mathrm{Fe}_{2} \mathrm{O}_{3}-\mathrm{MnO}-\mathrm{ZnO}-\mathrm{O}$ [7]. The chemical composition of the slurry in comparison to produced FRS powder was within the range of error.

During FRS the BET values decreased from $10.2 \mathrm{~m}^{2} / \mathrm{g}$ (activated slurry) to about $3.4 \mathrm{~m}^{2} / \mathrm{g}$ (FRS product). The early stages of FRS may contribute to an even higher specific surface area of the reaction components due to the formation of active metal oxides in status nascendi originating from decomposition reactions. During the final stages of FRS the release of stored energy [8], occurs very rapidly superposed by excellent heat and material transfer conditions. Sintering at this stage is similar to the final sintering mechanism in coprecipitated ferrite powders.
The extent of grain growth which was favoured at the presence of metastable liquid phases (occuring in commercial purity raw materials) may precisely be controlled within the range of a few tenth to a few microns average crystal size by means of adjusting the process parameters. This fact has been confirmed on a series of tests, which for its size may be considered industrial.

In order to get an idea about the particle size distribution of produced FRS powders scanning electron micrographs (SEM) have been prepared. The micrographs shown in figure 3 indicate that FRS processed metal oxides consist of agglomerates in the order of 40 to $200 \mu$. These agglomerates are built up by uniform primary particles exhibiting diameters within the micron range. According to a quantitative electron microscopic analysis more than eighty percent
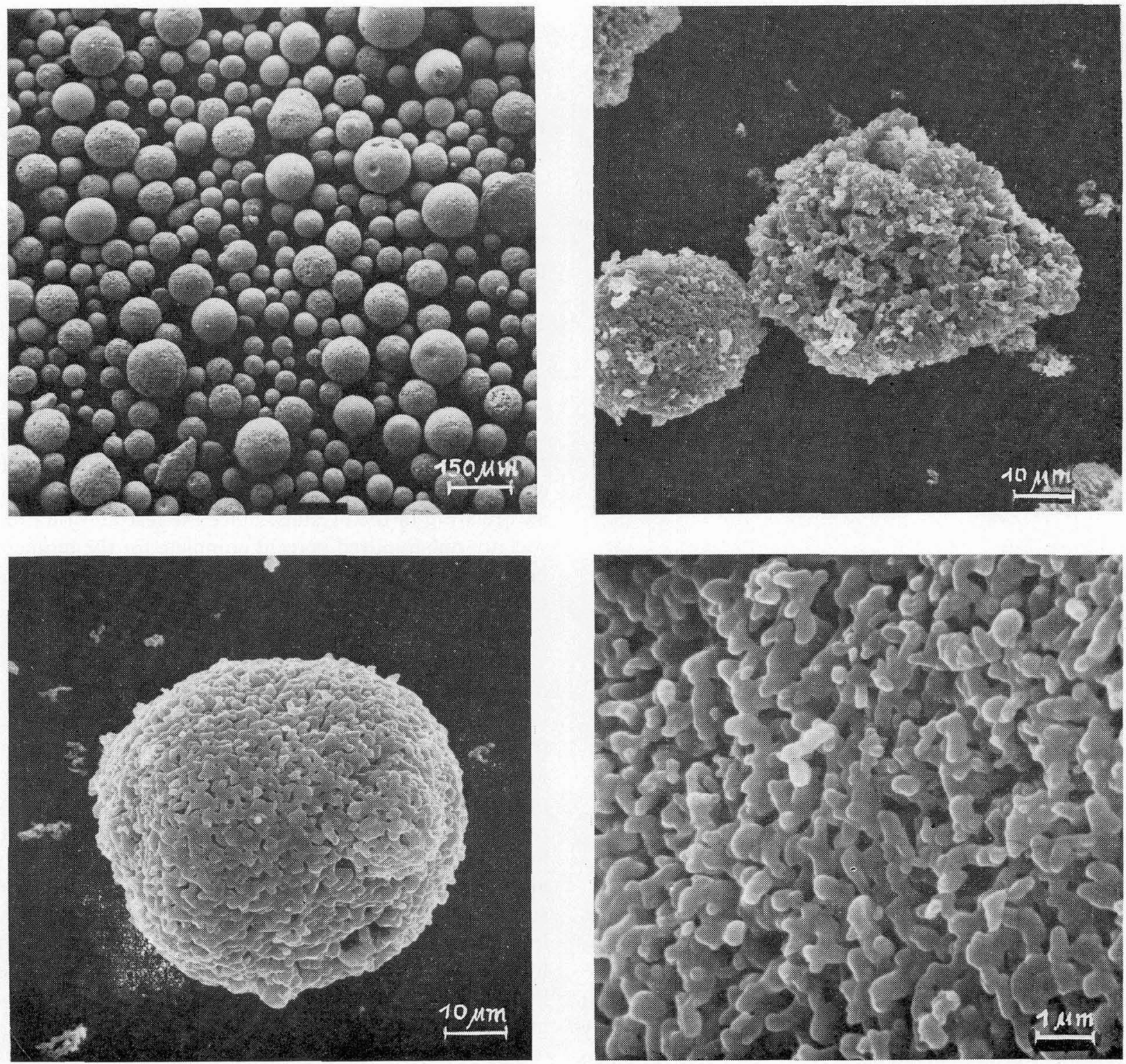

FIG. 3. - Scanning electron micrographs of manganese zinc ferrite powder produced at $950^{\circ} \mathrm{C}$ within 5 seconds by means of fast reaction sintering 
of individual crystal sizes are in the range of 0.1 to $0.6 \mu$.

After sintering the FRS powder underwent a deagglomeration procedure. Depending on further processing this operation may be accomplished by wet or dry milling. Due to the specific structure of FRS powders this operation may rapidly be accomplished with limited amounts of impurity pick up. The time necessary for deagglomeration depends to the extent of the neck radii of individual ferrite crystals.

Further processing of FRS manganese zinc ferrite powders to sintered products has been carried out by Siemens AG. The results, which are in accordance with strict quality requirements are subject of a forthcoming publication.

So far it has been stated that FRS processed ferrite powders yield a cleaner product in comparison to conventional methods. In addition some facts which are considered to be of advantage will be summarized in the conclusions of this paper.

8. Hard ferrites. - Presintered barium and strontium ferrite powders require an almost one hundred percent hexaferrite formation. The conventional presintering temperatures are in the order of $1250^{\circ} \mathrm{C}$ to $1400^{\circ} \mathrm{C}$. FRS experiments have been carried out on bariumhexaferrites $\left(\mathrm{Ba} 0.5,5 \mathrm{Fe}_{2} \mathrm{O}_{3}\right)$ using spray roasted ferric oxide, technical grade barium carbonate as well as active silica as raw materials. Some results which have been plotted in figure 4

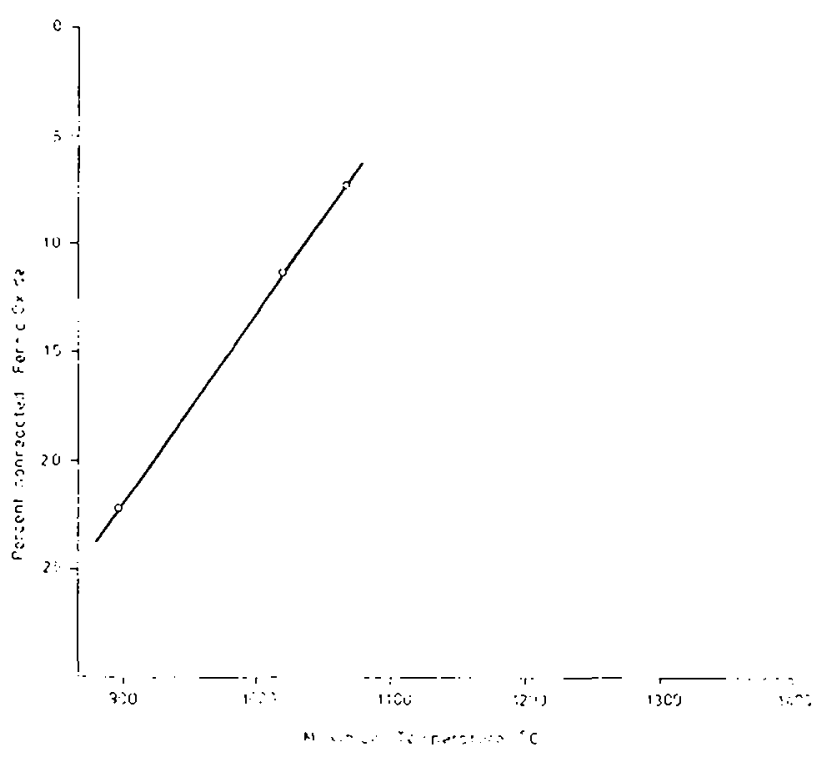

FIG. 4. - Formation of bariumhexafcrrite by means of fast reaction sintering free ferric oxide vs. max. sintering tempcrature.

indicate that bariumhexaferrite formation may at $1050^{\circ} \mathrm{C}$ be accomplished to an extent over ninety percent. Beside bariumhexaferrite and ferric oxide no other crystalline phase have been detected by means of X-ray measurements.
The results of bariumhexaferrite experiments indicate that complete hexaferrite formation may possibly be accomplished by increasing the firing temperature to $1200^{\circ} \mathrm{C}$. Further activation of the raw material slurry is considered to provide additional energy necessary for completion of hexaferrite formation. The influence of mechanical activation on the extent of hexaferrite formation may be seen by consulting the experimental data of two tests which are presented in figure 5 . The results indicate that the production of

\begin{tabular}{|c|c|c|c|}
\hline & & \multicolumn{2}{|c|}{ FRS-Bariumhexaferrit } \\
\hline & Item & Test A & Test $\mathbf{B}$ \\
\hline \multirow{3}{*}{ Sturry } & wt $\%$ solids & 45 & 45 \\
\hline & BET S. A. $\mathrm{m}^{2 / g}$ & 12.7 & 7.0 \\
\hline & av. Particle size $\mu \mathrm{m}$ & 0.09 & 0.16 \\
\hline \multirow[t]{2}{*}{ Furnace } & Temperature ${ }^{\circ} \mathrm{C}$ & 1065 & 1050 \\
\hline & Excess oxygen vol. \% & 2.5 & 3.2 \\
\hline \multirow[t]{5}{*}{ FRS Product } & BET S. A. $\mathrm{m}^{2} / \mathrm{g}$ & 0.9 & 2.2 \\
\hline & av. Particle size $\mu \mathrm{m}$ & (1.25) & $(0.51)$ \\
\hline & Bulk density $\mathrm{g} / \mathrm{l}$ & 1600 & 1050 \\
\hline & $\%$ BF 6 formed & +90 & +65 \\
\hline & $\% \mathrm{Fe}_{2} \mathrm{O}_{3}$ nonreacted & 7 & 31 \\
\hline
\end{tabular}

FIG. 5. - Experimental results of partially reacted FRS bariumhexaferrite powder.

bariumhexaferrite powders exhibiting a controlled particle size may considerably be influenced by mechanical activation of the raw materials. Figure 6 shows SEM of FRS powder which has been sintered at a maximum temperature of $1050^{\circ} \mathrm{C}$ for 5 seconds. The platelets of some hexaferrite crystals are clearly to be seen. The average particle size of formed hexaferrite crystals was determinated by applying a rough estimate calculation from BET measurements. This estimate did however not take care of the hexagonal axis relation of the crystals. Since the ferrite formation was not one hundred percent complete for the moment being, no comments will be made on the properties of sintered products.

9. Conclusions. - FRS ensures the industrial production of reactive ferrite powders within tight limits of control. This method is considered to offer more freedom of action on handling process parameters. Minor deviations in raw materials data which affect the properties of presintered ferrite powders may very rapidly be adjusted by interrupting the material flow, alternating the properties of the activated slurry and resume operation. The accuracy of ferrite compositions benefits from extremly short processing times, less impurity pick up from fuel and combustion air little material losses due to high vapor pressures and limited or no impurity pick up on subsequent deagglomeration.

The possibility to overcome low temperature stable oxide phases, which are subject to substantial grain growth in conventional presintering processes and 

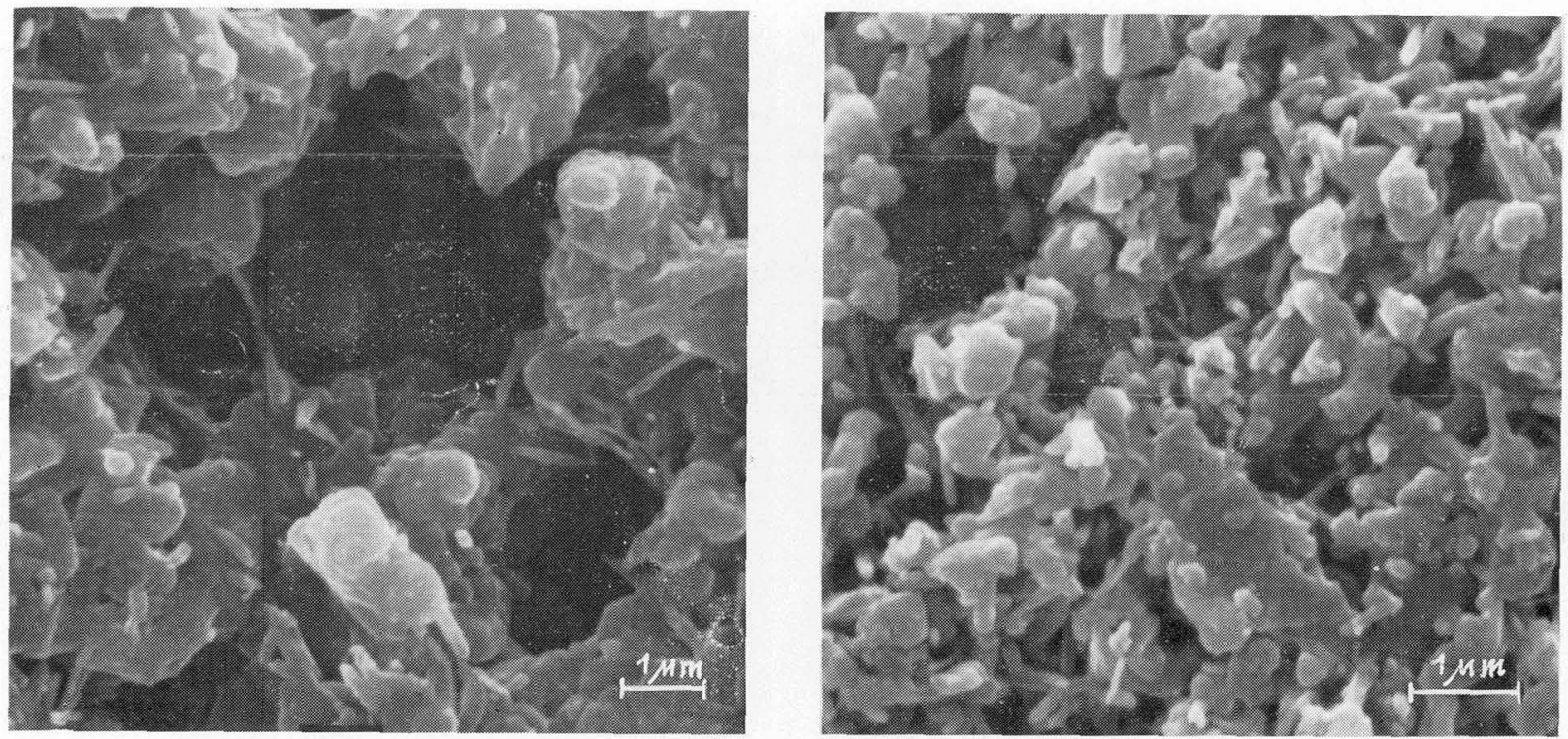

FIG. 6. - Scanning electron micrographs of barium hexaferrite powder produced ar $1050^{\circ} \mathrm{C}$ within 5 scconds by means of fast reaction sintering.

affect the time necessary to reach equilibrium conditions at higher temperatures is considered an additional advantage. Since the stored energy of the metal components becomes very rapidly free at elevated temperatures the average particle size developed inside the agglomerates was quite uniform and resulting average crystal size depended on the state of activation as well as on firing temperature.

FRS plants may be designed to operate at tempera- tures of more than $1400^{\circ} \mathrm{C}$. No pollution control or acid recycling equipment is essential. In order to take full advantage of the process raw materials exhibiting high specific surfaces are desirable.

Acknowledgements. - The author wishes to express his appreciation to Siemens AG of Munich and Ruthner Industrieanlagen $A G$ of Vienna for their permission to release some experimental results.

\section{References}

[1] Ruthner, M. J., Science of Sintering Vol. 6, No. 1/2, pp. 81-94. 1974.

[2] Ruthnfr, M. J., Richter, H. G., Stfiner, I. L., "Ferrites" Proceedings Int. Conf. Kyoto, 1970, pp. 75-78.

[3] Steinort, E., Proceedings 3rd Europ. Conf. Hard. Mag. Mat., Amsterdam 1974, 99, 66-69.

[4] Van den Broeck, C. A. M., Proceedings 3rd Europ. Conf. Hard. Mag. Mat., Amsterdam 1974, pp. 53-61.

[5] Fagheratzi, G., Ceramurgia 6 1976, 26-32.
[6] Hiragia, T., "Ferrites" Proceedings Int. Cong. Kyoto 1970, pp. 179-182.

[7] StICK, P. I., "Ferrites» Proceedings Int. Conf. Kyoto 1970 , pp. 81-83.

[8] Cilang, M. C., Ruthner, M. J., "Iron Oxide Bonding» 27th Ironmaking Conf. AIME, Atlantic City, N. J., 1968.

[9] Brunauer, S., Emmet, P. H., Teller, E., J. amer. Chem. Soc, 60 (1938) 309. 